\title{
Forest Conflict on the Forest Resources Management between Indigenous People and the Logging Company in Small Island
}

\author{
Gun Mardiatmoko, Thomas Melianus Silaya and Jan Willem Hatulesila \\ Forestry Department, Faculty of Agriculture, University of Pattimura, Ambon 97233, Indonesia
}

\begin{abstract}
Many conflicts are reported in small islands mainly in Eastern region of Indonesia and it is needed to conflict resolution in the forest sector. The research has been conducted on forest conflict in the small island of Yamdena. The aims of the research were: (1) to determine the customary rights of indigenous peoples to the forest area that was claimed as theirs according to the applicable rules and regulations; (2) to study the causes of conflict between indigenous peoples and the logging company; (3) to analyze the policy in the forest resources management on the customary land. This research is qualitative and uses a case study methodology. Data collection methods used include semi-structured interviews, participant observation and focus group discussion (FGD). The results showed that indigenous peoples whose livelihood is highly dependent on the forest were most threatened because of forest exploitation of their traditional land by the logging company. Handling of the conflict potential in the forest resources management in Yamdena island was approached through use of traditional laws, involving all the relevant parties to the conflict. The forest management either by indigenous peoples or the logging company is no longer focused on the timber harvesting but more on conservation aspects.
\end{abstract}

Key words: Forest conflict, forest concession, customary rights, social forestry.

\section{Introduction}

Social disharmony in management and utilization of the forest resources is an important issue, and if not overcome, it can lead to violent acts, such as burning the base camp and its heavy equipment, blocking the logging road, unilateral closure of the company activities by the community, etc.. Forest conflict between land users and multidimensional forest is basically the core of sociological forestry problems both on a local scale as well as a regional and national scale. These circumstances lead to disharmony among forest users in realizing sustainable forest management. Sustainable forest management is the process of managing forest to achieve one or more clearly specified objectives of management with regard to the production of a continuous flow of desired forest

\footnotetext{
Corresponding author: Gun Mardiatmoko, Ph.D., research field: forest management. E-mail: g.mardiatmoko@faperta.unpatti.ac.id.
}

products and services without undue reduction of its inherent values and future productivity and without undue undesirable effects on the physical and social environment [1]. Sustainable forest management is what the consumer demands in green products which have been internationally agreed upon to be implemented at the beginning of the 21 st century.

Indonesia's tropical rainforest area of 123.5 million ha is spread across both large and small islands. Forestland in Indonesia comprises $50 \%-60 \%$ of the country's land area. One province whose territory is largely dominated by small islands is Maluku province with a forest area of approximately 5.6 million ha, having timber potential and a high rate of non-timber forest products. Yamdena island in Maluku with good forest potential is one of the small islands bordering the Australian region. One important problem associated with management and utilization of the forest resources in Yamdena island today is the 
lack of harmony among the interested parties, i.e., indigenous peoples, the logging company and government. This lack of harmony has become a trigger for frequent of demonstrations in Saumlaki (capital of district), Ambon (capital of Maluku province) and Jakarta (capital of Republic of Indonesia) conducted by various parties on behalf of indigenous peoples in Yamdena island. Thus, these problems need to be solved at a district, provincial and national level. Forest conflict including illegal logging, land tenure, illegal trade, etc., has triggered forest degradation and deforestation in almost all forest areas in Indonesia. It has contributed significantly to global warming, and Indonesia today is the third largest emitter of green house gasses in the world after the United States and China. Forest conflict is still going on until now because of weak law enforcement. Indonesia has adequate forest laws and regulations in place, but they are often incompletely or not all implemented. This can be attributed to various causes, including the size of the country, limited resources available for law enforcement, remoteness of forest areas and minimal infrastructure in many places. This makes widespread forest crime difficult to be monitored through traditional methods (forest ranger, reports from concerned citizens, etc.). Institutional constraints also hamper the functioning of laws. Within the ministry of forestry in particular, there is no adequate or systematic flow of information among different directorates, except through prescribed narrow channels [2]. Outside of the ministry of forestry, communication among other ministries is limited. The situation was worsened by the government and military taking sides with the logging company which was feuding with the traditional community/indigenous peoples [3] and also by the presence of corruption in the military, forest agencies, forest related bureaucracies and the judiciary [4-6].

Disharmony in forest management has become a real obstacle in the sustainable forest management process, because of the conflict resulting in the absence of incentives and the uncertainty in use of the forest in Yamdena island. Moreover, there is a higher indifference to the future of forest resources utilized by the logging company, which only thinks in short-term forest management in terms of financial benefit to the company, but ignores the welfare of the communities around the forest.

The poor relationship between indigenous people and the logging company as the actors in management and utilization of forest resources, is an important issue that needs the attention of all parties to find the solution. Many people, such as investors and managers of development projects in the field of the forest enterprise, avoided this discussion topic. On the other hand, intellectuals, government policy makers, legislators and regulators as well as the non-governmental organization (NGO) activists in Indonesia considered this topic of high importance. The importance of this topic is because it is based on the national integration and democratization in utilization and management of the natural resources in Indonesia, including Maluku province.

\section{Methods}

\subsection{Study Region}

Yamdena island is the main island of the Tanimbar islands with several small islands around it, like Selaru, Sera, Selu, Wotar, Wuliaru, Labobar, etc.. Yamdena island lies between $07^{\circ} 06^{\prime} 13^{\prime \prime}-08^{\circ} 02^{\prime} 08^{\prime \prime} \mathrm{S}$ and $131^{\circ} 03^{\prime} 39^{\prime \prime}-131^{\circ} 45^{\prime} 09^{\prime \prime} \mathrm{E}$, and geographically has territorial boundaries as follows: the Flores sea in the North, the Arafura sea in the East, the Australian region in the South and the Banda sea in the West. In the region, there is a mountain called Mount Maloli with a peak altitude approximately $947 \mathrm{~m}$. Yamdena island which covers approximately 325,725 ha is the largest island in the Maluku Tenggara Barat (MTB) in the Maluku province. The island consists of five sub-districts, namely sub-district of Wertamrian, sub-district of Wermaktian, sub-district of Nirunmas, sub-district of Kormomolin and sub-district of South 
Tanimbar. Based on the land cover analysis [7], from the area of Yamdena island of 325,725 ha, 99.23\% was covered by forest in 1998, but in 2008 it had been reduced to $70.15 \%$. So the forest degradation rate has reached $2.9 \%$ per year or 9,473 ha/year. The forest degradation rate in the forest area concession is 3,089 ha/year and outside of the forest concession area it is $6,384 \mathrm{ha} / \mathrm{year}$. The increased rate of road construction has also led to the increase of degradation. Yamdena island has had an increase in road construction with an added road area on average of 46,858 $\mathrm{m} /$ year. Furthermore, the ministry of forestry in 2009 through ministry of forestry decree No.117/Menhut-II/2009 gave a concession license to the company of Karya Jaya Berdikari, with a width of 93,980 ha; the annual allowable cut (AAC) is 6,212 ha/year and 91,098 $\mathrm{m}^{3} /$ year [7]. The issuing of a concession permit has triggered conflict between indigenous peoples and the logging company. Many stakeholders, like the local
NGOs, religious leaders to the international institutions such as the EU, French CIRAD and Bird Life, are worried about the spread of the forest degradation indicated by more reduction in the forest cover, if the company of Karya Jaya Berdikari realizes a forest exploitation of 6,212 ha/year and 91,098 $\mathrm{m}^{3} /$ year. The location map of Yamdena island in Maluku is presented in Fig. 1.

\subsection{Data Analysis}

The research location was chosen after searching previous research results, and four villages were then defined by purposive sampling, namely Wermatang (in sub-district Wermaktian), Tumbur and Lorulung (in sub-district Wertamrian) and Lermatang (in sub-district of South Tanimbar). The basis for determining the research location were: (1) the village had a conflict related to forest resources; (2) $80 \%$ of the village area is located in the forest production area,

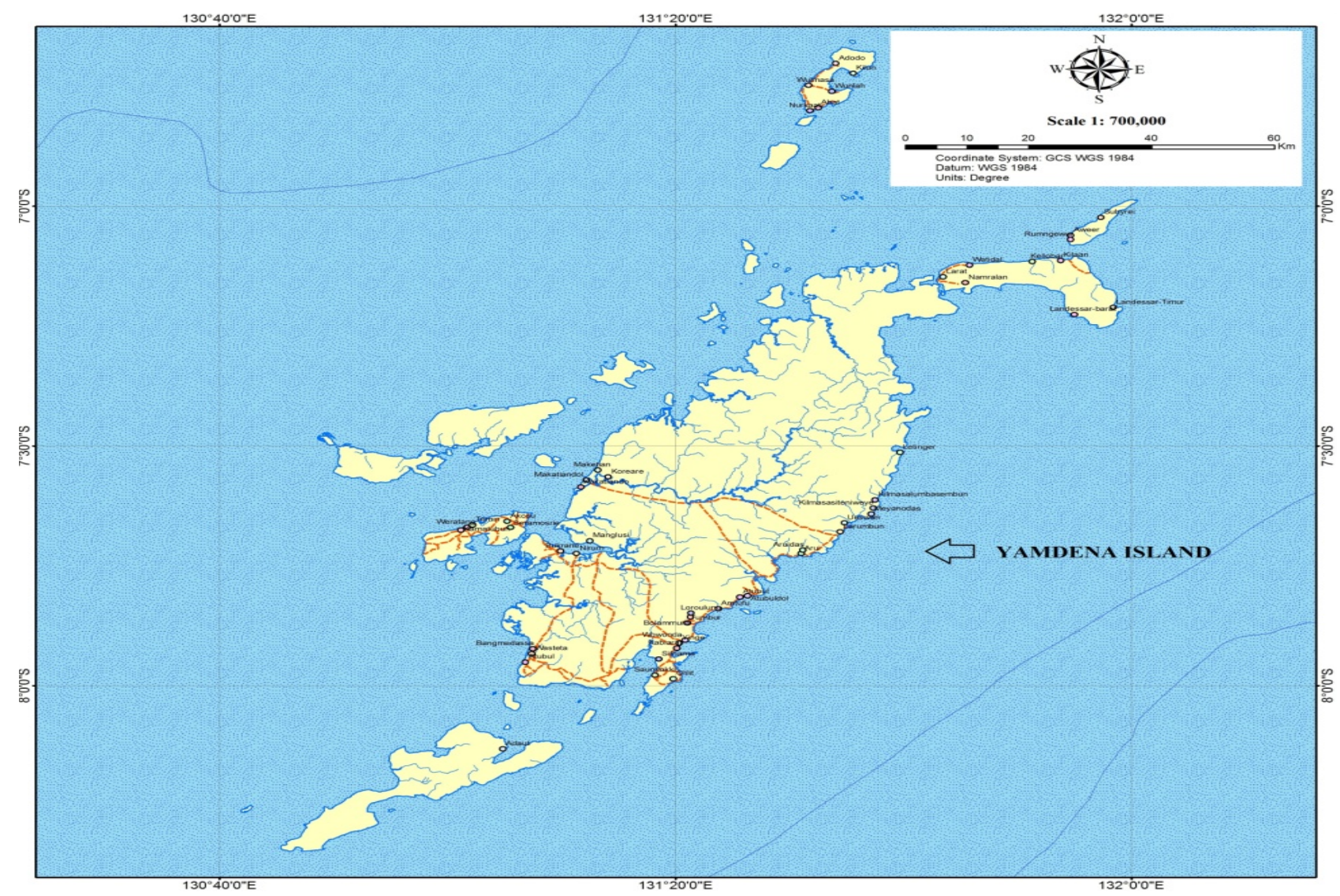

Fig. 1 Location map of Yamdena island in Maluku.

Source: geospatial information agency [8]. 
in which there is a logging operation; (3) research supporting data has the availability. The research was conducted in June 2010-February 2012. This research is qualitative and uses a case study method. The case study approach used is flexible and can be changed at any time in accordance with development of the empirical facts being observed. Data collection methods used consisted of: (1) semi-structured interviews are three times and the respondent from keyperson and village government is eight persons. Topic of interviews are sort history of forest management, activities of forest management by indigenous people, property rights of forest resources and conflict resources in forest management and conflict resolution through customary value approach; (2) participants observe to monitor the activity of indigenous people and customary institution directly on forest management. The next step is coordination with village government to select five households; (3) focus group discussion (FGD). FGD has been done in village office, each village has one time and every group discussion has five peoples. Topics of discussion are closely related to some questions from the resuts of the interview and participant observation. Semi-structured interviews were conducted with key informants to collect qualitative data using the snowballing technique. This involved participants based on perception of being well informed and leaders in the community to identify themselves and others for interview [9]. Historical analysis was used to analyze from the origins of the sample village up to the environmental changes arising from management activities of the forest resources by the forest enterprise and the local communities. The causal relation analysis is used to explain a phenomenon by establishing a reciprocal linked series on the phenomenon. The subjective assessment analysis is used to understand the subject's perspective in assessing the customary institutions' performance in the sample villages post-conflict. Collection data from interview, observation and FGD are saparated based on the aims of research. The next step is to make category based on their data target and then to search relation of data target from one to another to get interpretation and research conclusion.

\section{Results and Discussion}

\subsection{The Customary Rights of Indigenous Peoples upon the Forest Region in Yamdena Island}

The village communities in Yamdena island have a kinship system, and the structure and community system are based on tradition passed down from generation to generation. The kinship system adopted is based on the father's lineage, known as a patrilineal lineage system. This system became the basis of the kinship order, marriage norms as well as the inheritance mechanism. Social system in the villages surveyed had some forms of group unity or social and family unit known as households, marga (clans) and soa (a group of marga). The community lives in the traditional law areas that are closely related to the ulayat rights (or customary rights) of a village. Some common features of the ulayat rights include: (1) the existence of a relationship between the indigenous peoples and their land or environment as a unit that cannot be separated; (2) the existence of opportunities for residents outside the indigenous peoples unit to be able to benefit from the land by paying appropriate compensation; (3) the existence of collectives that can be utilized by all residents of the particular indigenous peoples communion, by limiting the freedom to dominate individually. The ulayat right of a negeri (traditional village, there is the lowest govermental level in Maluku province) on the mainland is not only about the land, but also includes the forests, rivers and its entire production. Therefore, the forest should be used as much as possible for the people's welfare. Control of the land and traditional forests through the ulayat rights, is not just a matter of control, but its utilization should also be run in an orderly manner, since the land, forests, sea and all they contain are a 
community "storehouse" and the main source of income to the community. The saniri agency is the holder and implementer of the sovereign rights and the customary institution which decides the forms of utilization and management of the natural resources, including the forests owned by a village or traditional "country". Determination of the village area boundaries is based on several sources, namely, the basic map, village monograph data and information from the state government staff and customary leaders. The village boundary markers are usually in form of the natural boundaries, such as rivers, mountains, sea and others natural markers [10]. Based on the results of the study conducted, it was found that customary institutions in the Yamdena island are very varied, ranging from those which are weakly binding (for example, illegal exploitation of fuelwoods) to those which are very strongly binding (for example, illegal loging). If the traditions are violated, the community will be subject to very strict sanctions.

Compiling sets of rules or provisions on customary law is a social control system as well as a normative aspect of living together. The rules are a way of life for the community of Yamdena island as part of living together and for managing the forests and its environment. Some rules contain sanctions and others do not. The latter are traditions or habits (habits carried out from generation to generation, which have been entrenched in everyday life). Transgression against a tradition, even although there is no sanction, will incur vocal dissent, since that tradition is a reflection of personality and the embodiment of their spirit from generation to generation. On the other hand, the rules containing sanctions are customary law. Every transgression committing against customary law will be penalized according to the local customary regulations. In practice, it is not easy to distinguish between traditional and customary law for the scientists, and in modern society, in general, the traditional rule is now called the law.

Community life in the villages studied (based on the result of interview, participant observation and FGD) contained a number of customary law or tradition governing the relationship among the communities with each other and between the community and its environment. The customary law or tradition is the manifestation of the community wisdom in maintaining the congeniality and harmony with its environment natural. There was also a concern and responsibility of the community to foster and develop norms in the living relationships among people.

\subsection{Forest Management and Community Tradition} against the Forest Resources in the Study Region

Based on observation forum in all of four sample villages, the main traditional systems for forest protection in the research location are classified into two groups - sasi and pamali.

The management of customary land (petuanan) is based on the "eating together" sharing principle. Land is not owned by individuals, but the cultivation rights can be passed on to the next generation. Within the petuanan, the traditional system for managing natural resources is known as sasi [11]. Sasi is rules which must be obeyed by every community resident. In general, there are two types of sasi systems which are often implemented, i.e., country sasi and church sasi. The country sasi is, in its traditional ceremony, conducted by the village elders communicating or talking to ancestor's spirits. Implementation of the sasi began with the closing ceremony of sasi, indicating the existence of regulation that the community is prohibited to harvest any existing plants in the traditional region. Furthermore, at certain times after 4-6 months, the sasi open ceremony was conducted again to indicate that the community was now permitted to harvest the plants in that area. Today, the country sasi is rare, but there are still many church sasi conducted, beginning with a prayer in the church.

The sacred place (pamali) is a place that has supernatural powers or magical power. Olyali forest, Watifira, Abatiubu, Aryatu and Falosa river have been 
established as sacred places by indigenous people. Therefore, in these forest regions, no logging, hunting or taking of other forest products can be carried out, which has maintained the preservation of these forests. Forest, to the community in Yamdena island, is understood as an integral part of their lives. For indigenous peoples, the forest is a food resource (plants and animals), a source of medicine, a place for farming/cultivating a non irrigated field and a source of wood for fires and building, etc.. This shows the community's dependence on its forest resources. Poor people, often dependent on common property resources, are particularly dependent on forests for food. Many have a reasonably varied diet. The consumption of meat can be very high, raising serious concerns about sustainability of wildlife populations in many places. Forests also supply goods that are indirectly important for the provision and preparation of food, like poles, fodder and fuel. Therefore, forest resources are vitally important for rural livelihood and local businesses which rely on timber and other forest products [12]. In addition, the forest landscape serves to maintain a fresh water supply, stabilize soil and permafrost and provide diverse habitats for wildlife. With effective forest management, it can also provide a secure supply of forest products that could meet the demands of population growth [13]. The forest plays an important role in the livelihood to provide staple and supplemental foods, timber, firewood, fodder, litter, farm inputs, medicines and commercial forest products that generate cash income. The contribution of the forest in their food security is even more significant, as they provide not only the staple foods that help to overcome the food shortages but also a number of dietary elements through supplemental food [14]. Besides, forest play a crucial role in the hydrological cycle. They influence the amount of water available and regulate surface and groundwater flows while maintaining high water quality [15].

Based on observations forum and FGD, the community's dependence relationship on their forest resources in Yamdena island can be described as follows:

(1) Forest as food resources

History of human civilization is already very old and has already undergone a process of social and cultural change over the thousands of years. In the change process, the civilization that has survived until now is the one which is able to defend itself. When looking at the development of self defence in man, before becoming a farmer, firstly man looked for food already provided by nature within the surrounding environment. At that time, people tended to collect food from the surrounding forests. This proves that, step by step, humans/society gradually began to break away from the primary dependence on the hunting and gathering way of life that was experienced over thousands of years. Although these changes have taken place over a long time, it does not mean that all human beings have undergone a thoroughly social transformation. For the community of Yamdena island who still live in a forest ecosystem, with all the limitations of transformation, communication, trade and technology, the activity of looking for foodstuff, medicines and other forest products (hunting and gathering) is still part of their lives.

(2) Shifting cultivation

Shifting cultivation is the oldest agricultural system in the tropics. For the community in Yamdena island, shifting cultivation is the ancestral heritage and is easy to implement, because it uses simple technology, such as axes, fire and digger/drill (still some use hoes and crowbars). The farming activities in the community began by firstly finding a location for their fields. The farmers must fulfill the specific requirements of informing bapak raja (village head), tuan tanah (regulator of the rights of customary land in the village) and kewang (supervisor of the natural resource management/the rangers in the village). After obtaining permission, the farmers begin looking for fertile land and planting tubers, bananas, corn, beans and vegetables, including multi-purpose trees. 
(3) Forest as the energy and timber producer

Indigenous peoples have always utilized the forest timber depending on its quality, for example to build houses they use a durable hardwood type. For cooking, they take firewood, which provides the energy source for the villagers in Yamdena island. The firewood, besides being easy to obtain and readily available, is free. The wood collected for firewood is from old, dried and fallen trees or the dried twigs and branches of dry wood fallen to the ground.

Realizing the importance of forests, indigenous people always work to maintain and preserve the forest in order to remain sustainable. This information is collected from the FGD and observations forum. There was conflict between the logging company and indigenous peoples in Yamdena island. Since the existence of forests has both benefit and impacts on the nation, all forest areas in Indonesia and all resources therein are controlled by the state. Therefore, article 4 of the Forestry Act No. 41/1999 [16] states that all forests are under control of the state for the maximum benefit of the people. With this control, the state has obligations to assign and mantain certain areas as pemanent forest zones for protection, conservation and utilization purpose. The government, within existing laws and regulations, has granted concessions to private and state forest enterprises to manage and derive benefits from production forest, mainly through timber extraction. The government has also set out rules to regulate forest management operations, and plantation and timber harvests in production forests are managed by concession holders. Communities, who live on the fringes of and within forest zones, are granted rights to utilize timber and other products from the forest for daily consumption and livelihood. These rights are considered to be marginal compared to those given to the concession holders, since the community only gets their subsistence from the forest, while the greater benefits from the forest are enjoyed by concession holders. Legally, a community would get similar benefits, only if it establishes an eligible cooperative to operate a forest concession. Unfortunately, most communities lack sufficient capital to prove their eligibility and to comply with the requirements set out for competent forest operators. Therefore, conflicts among communities, government and concession holders in the production forest zone always begin, when the communities are restricted from cutting timber for commercial use, and they believe using the land is their inheritance from their ancestors [17]. Conflicts among communities, government and the forest concession holders occur not only in major islands in Indonesia, like Sumatra, Java, Kalimantan and Papua, but also on small islands in Maluku, including Yamdena island. Forest exploitation in Yamdena island first initiated in 1991 by the concession holders, the company of Alam Nusa Segar with the minister of forestry decree No. 215/Kpts-II/1991 with an area of 164,000 ha [7]. Furthermore, in addendum of the minister of forestry decree No. 1107/Kpts-II/1992 [7], it was renamed with PT. Yamdena Hutan Lestari with an area of 160,725 ha. Since this logging company was conducting over exploitation and the existence of prolonged conflict with indigenous peoples, the minister of forestry revoked the forest concession with the revocation decree No. 200/Menhut II/2007 on May 16, 2007 [7]. During the period of the logging operation, there was a mild to severe conflicts between indigenous peoples who received support from NGOs, mass organization, religious institutions and Tanimbarese scholars with the logging company backed by government and Indonesia military police. In addition, illegal logging activities occurred both in the forest concession area as well as outside it. Dissatisfaction of indigenous peoples about the forest management activities has also been addressed indirectly to government or the minister of forestry, since they set up the concessions policy. In some cases, conflicts between indigenous peoples and the logging company always held to the rules or policies of government. But communities were not brave 
enough to oppose the central government, especially before the decentralization era, including openly resisting the employers. After the fall of president Suharto and the beginning of the reformation era, the real effort of the community in opposing the logging company was more open, daring and sometimes followed by anarchist action.

Besides the forest degradation, the logging exploitation has also resulted in the shift of local values on forest management in some areas, where those who have already changed to using a chainsaw before felling trees with a chopper. This can be understood as that the traditional community tends to be dynamic; from time to time, there is change as a process of adaptation in accordance with development. This has led indirectly to a greater spread of illegal logging both within and outside the forest concession area. In the case of the illegal loggers, it needs to be clarified whether they are from indigenous peoples/customary community, local community or newly arrived community [17].

With the inclusion of the logging company and exploitation of the forest in most of the customary areas, there has been a sharpening conflict between the logging company and indigenous peoples. Forest related conflict in Yamdena island has similarities with study results in Southeast Cameroon, mainly local access to forest has been severely reduced and customary rights are restricted as an effect of the national forest zoning plan; in the both places, the access of local people to forests becoming limited may cause conflicts [18]. The conflict is based on competing views about what the right situation is and which resource user should have priority. The conflict materializes first of all in disagreements between the communities and the logging company over acces to forest resource. The state seems to clearly acknowledge that logging and traditional uses are not compatible. As it gives priority to logging, it leaves it up to the logging companies to handle the conflicts on the ground. This creates a confusion: where the local communities are deprived, at least in practice, from the fundamental issue - defining their rights to forest livelihoods? Local communities seem therefore "trapped" between the company and state officials. They cannot attack the company neither for deficiencies in the law nor for the concessions which has legally acquired according to this law. Factors that were cause of conflicts in some villages in Yamdena island are presented in Table 1.

The presence of indigenous peoples and its customary land was actually acknowledged by government as contained in the Forestry Act No. 41/1999 and the Agrarian Minister Regulation No. $5 / 1999$ [16], but in the field was not well coordinated. As a consequence, the forest conflict has continued in Yamdena island and seems very difficult to stop. This needs serious attention from the government, because the rights of indigenous peoples have been recognized by the United Nations declaration on the rights of indigenous peoples article 17 [19], "indigenous individuals and peoples have the right to enjoy fully all rights established under applicable international and domestic labor law", also article 26 [19], "indigenous peoples have the right to the lands, territories and resources which they have traditionally owned, occupied or otherwise used or acquired; indigenous peoples have the right to own, use develop and control the lands, territories and resources that they posses by reason of traditional occupation or use, as well as those they have otherwise acquired" [19].

The parties in dispute people whether from indigenous peoples, logging company or government look to have met a stumbling block in the form of an inability to complete tasks and to follow through. It can be illustrated that the lives of these people often seem to embody Zeno's paradox. In this paradox, a man wishes to get from point $A$ to point $B$. In order to traverse the distance, he has to traverse half the distance. In order to traverse the remaining half of the distance, he first has to traverse half of that distance, leaving one quarter of the total distance remaining to 
Table 1 The causes of conflict between the forest concession and indigenous people in Yamdena island.

\begin{tabular}{|c|c|c|c|c|}
\hline \multirow{2}{*}{$\begin{array}{l}\text { Village } \\
\text { name }\end{array}$} & \multirow{2}{*}{ Year } & \multicolumn{3}{|c|}{ Background of conflict between the forest concession and indigenous people } \\
\hline & & Logging company & Deal & Source/cause factors \\
\hline Tumbur & 1991-1992 & $\begin{array}{l}\text { PT. Nusa Alam Segar/PT. } \\
\text { Yamdena Hutani Lestari, } \\
\text { business license in the } \\
\text { petuanan area of Tumbur } \\
\text { village }\end{array}$ & $\begin{array}{l}\text { Entering the customary land to } \\
\text { take the timber with the following } \\
\text { requirements: } \\
\text { Selective logging; } \\
\text { Replanting; } \\
\text { Construct facilities and } \\
\text { infrastructure; } \\
\text { Appropriate compensation. }\end{array}$ & $\begin{array}{l}\text { Logging company did not execute a deal } \\
\text { in accordance with the agreement made } \\
\text { in custom; } \\
\text { Recruitment of workforce only in one } \\
\text { village; } \\
\text { Distribution of tribute to the village is not } \\
\text { equal in amount; } \\
\text { Construction of facilities and } \\
\text { infrastructure is different in each village; } \\
\text { Timber logging enters the petuanan of } \\
\text { other villages; } \\
\text { Social resentment of placement of the } \\
\text { workforce. }\end{array}$ \\
\hline Ilngei & 1991-1992 & $\begin{array}{l}\text { PT. Alam Nusa Segar/PT. } \\
\text { Yamdena Hutani Lestari }\end{array}$ & $\begin{array}{l}\text { Logging company enters the } \\
\text { customary land to take the timber } \\
\text { without agreement with indigenous } \\
\text { peoples. }\end{array}$ & $\begin{array}{l}\text { Logging enters the customary land of } \\
\text { Ilngei village without prior consultation. }\end{array}$ \\
\hline Marantutul & 1991-1992 & $\begin{array}{l}\text { PT. Alam Nusa Segar/PT. } \\
\text { Yamdena Hutani Lestari }\end{array}$ & $\begin{array}{l}\text { Logging company enters the } \\
\text { customary land to take the timber } \\
\text { to the terms: } \\
\text { Only pay the timber compensation } \\
\text { to soa of the petuanan owner; } \\
\text { Made only by head of village. }\end{array}$ & $\begin{array}{l}\text { Logging is done only to the soa of the } \\
\text { petuanan owner while other soa not; } \\
\text { Pay compensation based on size of trees } \\
\text { used only; } \\
\text { Deal is performed with the village just to } \\
\text { pay retribution. }\end{array}$ \\
\hline Lorulung & 1995-1999 & $\begin{array}{l}\text { PT. AlamNusa Segar/PT. } \\
\text { Yamdena Hutani Lestari, } \\
\text { concession license in the } \\
\text { customary land of Lorulung } \\
\text { village and community } \\
\text { empowerment around the } \\
\text { forest of villages Lorulung }\end{array}$ & $\begin{array}{l}\text { The logging company takes the } \\
\text { timber with the following } \\
\text { requirements: } \\
\text { Agreements made with the } \\
\text { community; } \\
\text { Companies should fulfill the } \\
\text { community rights with assistance } \\
\text { of facilities and infrastructure } \\
\text { (roads, assistance of construction } \\
\text { material teak seedlings). }\end{array}$ & $\begin{array}{l}\text { Logging is done only on soa of the } \\
\text { petuanan owner; } \\
\text { Pay compensation based on size of trees } \\
\text { used only; } \\
\text { The company liability to empower the } \\
\text { community not in accordance with the } \\
\text { agreement. }\end{array}$ \\
\hline Wermatang & 2009-2010 & $\begin{array}{l}\text { PT. Karya Jaya Berdikari, } \\
\text { concession licenses at the } \\
\text { petuanan of Wermatang } \\
\text { village }\end{array}$ & $\begin{array}{l}\text { The logging company takes the } \\
\text { timber with the following } \\
\text { requirements: } \\
\text { The agreement must be done with } \\
\text { the village community; } \\
\text { Companies must fulfills the } \\
\text { community rights. }\end{array}$ & $\begin{array}{l}\text { Make agreement not involving soa Uduk } \\
\text { as the petuanan owner and other soa only } \\
\text { by head of village only. }\end{array}$ \\
\hline
\end{tabular}

be traversed. But in order to traverse that distance, he first has to complete half of that. In the paradox, the man always goes half of the remaining distance and never arrives. Similiarly, some peoples seem unable to reach the ends of situations [20].

Based on results of the FGD, the views obtained showed why indigenous peoples do not like the presence of logging company in their customary lands, i.e., (1) community feels there has been a breach of culture, where with the permission obtained from government, employers retain and utilize community resources and living space; (2) the presence of the logging company has narrowed the space and accessibility of community to the forest resources, with various restrictions against the community activities around the forest; (3) the forest exploitation activities themselves do not provide significant positive benefits to the community, only the damage 
to living environment remains; (4) domination and concession of forest resources have eliminated and deprived the rights as well as the future of indigenous peoples. Given the conflict cannot be resolved through diplomatic means, then indigenous people from Arma village began to shed their anger by burning the base camp of PT. Karya Jaya Berdikari in mid year 2012. Consequently, 36 Arma villagers were arrested by local police. The incident has also encouraged the influential religious figure in Maluku, the Amboina Bishop to pressure the central government represented by the minister of forestry to immediately revoke the license of PT. Karya Jaya Berdikari, and if not complied he would use international pressure to resolve it. Based on FGD results, overcoming a pattern of conflict can be done through the customary values approach by involving various stakeholders as presented in Table 2.

\subsection{The Policy of Forest Resources Management of Yamdena Island}

Forest resources in Yamdena island are multifunctional and related to the livelihood needs of people and other living beings on this earth. Therefore, there needs to be some attention paid to forest resources management in Yamdena island. This concern needs to be expressed in terms of a policy, such as the regulations contained in the cultural value system of indigenous people and rules and regulations at the local, national and international level. In order that management policy of forest resources can be implemented well, there is need for a strong common commitment. One effort which could help to realize this common commitment is to have a common understanding of which is democratic, accommodative and transparent. This common understanding should be listed in a written document signed by all parties interested in forest resources. The forest management policies by many parties in Yamdena island are presented in Table 3.

Based on the forest management policy presented in Table 3, then the neighboring villages or those in the forest areas exploited by the logging company were directed to implementation of the social forestry programs, such as the village forests, the community forests, etc.. As village assets, development of village forests or community forest needs some requirements, such as: (1) long-term management area assurance that it is related to land legality and community access to the region with the state forests status and other region that are different in status and its land functions; (2) the presence of community forestry venture institution (CFVI); (3) community forestry venture assurance is related to the economic scheme of village

Table 2 Solution of forest conflict in Yamdena island.

\begin{tabular}{|c|c|c|c|}
\hline \multicolumn{4}{|c|}{ Responsible person } \\
\hline Logging company & Village government & Sub-district government & District government \\
\hline $\begin{array}{l}\text { Preserving and maintaining the } \\
\text { forest area }\end{array}$ & $\begin{array}{l}\text { Making a village regulations on } \\
\text { the utilization of forest product }\end{array}$ & $\begin{array}{l}\text { Assisting to coordinate the } \\
\text { resolution of land conflicts and } \\
\text { the customary land (petuanan) }\end{array}$ & $\begin{array}{l}\text { Assisting the reinforcement } \\
\text { program of indigenous peoples }\end{array}$ \\
\hline Replanting the vacant land & $\begin{array}{l}\text { Regulating the forest } \\
\text { conservation with the cultivation } \\
\text { plant }\end{array}$ & $\begin{array}{l}\text { Making customary meeting } \\
\text { between the village forum }\end{array}$ & $\begin{array}{l}\text { Making regulations for indigenous } \\
\text { peoples and customary rights }\end{array}$ \\
\hline $\begin{array}{l}\text { Obeying the customary and } \\
\text { government regulations on the } \\
\text { forest management }\end{array}$ & $\begin{array}{l}\text { Prohibit logging by creating the } \\
\text { rules of village }\end{array}$ & $\begin{array}{l}\text { Performs coaching to villages } \\
\text { the causes of conflict }\end{array}$ & $\begin{array}{l}\text { Assisting the community } \\
\text { empowerment program through } \\
\text { the increase of social forestry } \\
\text { program }\end{array}$ \\
\hline $\begin{array}{l}\text { Stop the large-scale logging } \\
\text { but beginning focus on the } \\
\text { ecosystem restoration }\end{array}$ & $\begin{array}{l}\text { Upholding the customary } \\
\text { institutions in the forest } \\
\text { management }\end{array}$ & $\begin{array}{l}\text { Arranging resolution of land } \\
\text { conflicts between villages }\end{array}$ & $\begin{array}{l}\text { Providing extension to the } \\
\text { community in the conflict villages }\end{array}$ \\
\hline Logging for the families needs & $\begin{array}{l}\text { Monitoring and applying } \\
\text { sanctions in the forest } \\
\text { management }\end{array}$ & $\begin{array}{l}\text { Assisting the resolution of land } \\
\text { conflicts between citizens }\end{array}$ & $\begin{array}{l}\text { Making the Maluku Tenggara } \\
\text { Barat customary regulation and its } \\
\text { socialization }\end{array}$ \\
\hline
\end{tabular}


People and the Logging Company in Small Island

Table 3 The forest management policies by many parties on Yamdena island.

\begin{tabular}{|c|c|c|}
\hline Forest service & Community and village governments & $\begin{array}{l}\text { Regional government of Maluku } \\
\text { Tenggara Barat district }\end{array}$ \\
\hline $\begin{array}{l}\text { Establishment program of Bungai forest } \\
\text { management unit; } \\
\text { Community land management program; } \\
\text { Assistance program of farmers group. }\end{array}$ & $\begin{array}{l}\text { Preparing the farmers group; } \\
\text { Making data of forest products potential } \\
\text { being developed. }\end{array}$ & $\begin{array}{l}\text { Making regional regulations on the } \\
\text { customary rights; } \\
\text { Preparing common action program } \\
\text { between the conflict villages. }\end{array}$ \\
\hline $\begin{array}{l}\text { Socialization programs of the community } \\
\text { rights in accordance with legislation; } \\
\text { Community strengthening programs and } \\
\text { customary rights. }\end{array}$ & $\begin{array}{l}\text { Conducting the customary deliberation and } \\
\text { seeking for conflict resolution; } \\
\text { Make rules for agreement of eating } \\
\text { together. }\end{array}$ & $\begin{array}{l}\text { Making regional regulations concerning } \\
\text { the indigenous peoples; } \\
\text { Making indigenous empowerment } \\
\text { program. }\end{array}$ \\
\hline $\begin{array}{l}\text { Creating the land rehabilitation program; } \\
\text { Committing an assistance program on the } \\
\text { forest farmer group. }\end{array}$ & $\begin{array}{l}\text { Redesign the customary institute of eating } \\
\text { together; } \\
\text { Making village regulations on land use. }\end{array}$ & $\begin{array}{l}\text { Assisting resolution of land conflict } \\
\text { through customary meeting; } \\
\text { Providing assistance in equipment and } \\
\text { means of farming business. }\end{array}$ \\
\hline $\begin{array}{l}\text { Giving information on impact of the land } \\
\text { degradation; } \\
\text { Developing village forest/people forest } \\
\text { program and forest conservation program. }\end{array}$ & $\begin{array}{l}\text { Making village regulation on land use; } \\
\text { Making village regulation on prohibition of } \\
\text { destruction the forest/logging. }\end{array}$ & $\begin{array}{l}\text { Making regional regulations on resolution } \\
\text { of land conflict/petuanan; } \\
\text { Committing the mentoring program of } \\
\text { land conflict resolution. }\end{array}$ \\
\hline
\end{tabular}

forest development; (4) human resource capacity; (5) resolution mechanisms of land and social dispute in providing an assurance and protection of management rights and CFVI. This requirements have been clearly described in the Forestry Act No. 41/1999. From this study, it can be suggested that the village forest region in Yamdena island can be managed by: (1) management and utilization of small scale timber forest production adapted to the nature and characteristics of forests and the region's bio-physical conditions; (2) management and utilization of forest services, especially ecotourism; (3) biodiversity and carbon trading. In addition, the logging company is no longer focused on timber extraction but ecosystem restoration. Basically, the logging company from the outset is not directly exploiting the forest but making improvements in the forest, firstly by planting vacant land and enrichment planting, conservation of flora and fauna which are endangered in various places in the degraded forest by involving the local community. The activities are known as ecosystem restoration whose implementation permit is regulated in government regulation No. 6, 2007 [7]. After the logging company ensures that they have succeeded in conservation, only then will they start their activities for timber levy. Thus, it is a sympathetic and convincing step that the logging company does not only understand extracting the forest resources alone but is also capable of carrying out forest conservation. Both the increase of social forestry program for the community and the conservation programs of the company must be fully supported by central and regional governments, including support from NGOs, religious leaders and local scholars.

\section{Conclusions}

Forest conflict between the indigenous peoples and the logging company has caused financial loss not only to the warring parties, but has also led to degradation of forest resources on Yamdena island. Overcoming the conflict and conflict potential in forest resources management needs to be done through a customary law approach design by involving all parties in the forest conflict. In an effort to improve the welfare of indigenous people, governments need to promote the social forestry program through community and village forest, etc., while the logging company must change its management from forest exploitation to ecosystem restoration.

\section{Acknowledgments}

The authors would like to acknowledge the 
Directorate General of Higher Education, Ministy of National Education, Indonesia for the support on this research through competitive research grants in 2011.

\section{References}

[1] International Tropical Timber Organization (ITTO). 2011. "Sustainable Forest Management." Accessed June 21, 2014. http://www.itto.int/sustainable_forest_management/.

[2] Stolle, F., and Brown, D. W. 2009. "Bridging the Information Gap: Combating Illegal Logging in Indonesia." World Resources Institute Forest Note, Forest Governance in Southeast Asia. Accessed August 23, 2014. http://www.wri.org/publication/bridging-information-gap.

[3] Yasmi, Y., Kelley, L., and Enters, T. 2011. "Forest Conflict in Asia and the Role of Collective Action in Its Management.” CAPRI Working Paper No. 102, International Food Policy Research Institute, Washington, DC. Accesed March 23, 2014. http://dx.doi.org/ 10.2499/CAPRiWP102.

[4] De Koning, R. D., Capistrano, D., Yasmi, Y., and Cerutti, P. 2008. "Forest-Related Conflict: Impacts, Link and Measures to Mitigate.” The Right and Resources Initiative, Washington, DC. Accessed October 27, 2014. http://www.rightsandresources.org/documents/files/doc_8 22.pdf.

[5] Palmer, C. E. 2000. "The Extent and Causes of Illegal Logging: An Analysis of a Major Cause of Tropical Deforestation in Indonesia." CSERGE Working Paper, Economics Department, University College London, London. Accessed March 25, 2014. http://www.ucl.ac.uk/cserge/Illegal_Logging.pdf.

[6] Tacconi, L., Down, F., and Larmour, P. 2009. "Anti-corruption Policies in the Forest Sector and REDD+." In Realising REDD+: National Strategy and Policy Options. Bogor, Indonesia: CIFOR, 163-74.

[7] PT. Kurnia Sylva Consultindo. 2009. "Study on Forest Degradation in Yamdena Island, Maluku." Accessed March 1, 2015. http://www.dephut.go.id/files/Kajian_ Degradasi_Yamdena_1998_2008.pdf. (in Indonesian)

[8] Badan Informasi Geospasial. 2012. "The Thematic Map of Geospatial Information Agency." Accessed July 17, 2013. http://www.bakosurtanal.go.id. (in Indonesian)

[9] Chevalier, J. 2001. Stakeholder Analysis and Natural
Resource Management. Report on Stakeholders Information System for Carleton University, Ottawa.

[10] Lokollo, J. 2006. The Ulayat Right of Indigenous Peoples in Maluku Tengah Region. University of Pattimura, Ambon. (in Indonesian)

[11] Laumonier, I., Bourgeois, R., and Pfund, J. L. 2008. "Accounting for the Ecological Dimension in Participatory Research and Development: Lesson Learned from Indonesia and Madagascar." Ecology and Society 13 (1): 15. Accessed August 27, 2014. http://www. ecologyandsociety.org/vol13/iss1/art15/.

[12] Colfer, C. J. P., Sheil, D., and Kishi, M. 2006. "Forest and Human Health: Assessing the Evidence." CIFOR Occasional Paper No. 45, CIFOR, Bogor, Indonesia. Accessed June 21, 2014. http://www.cifor.org/ publications/ pdf_files/research/livelihood/forest_health/pdf13.pdf.

[13] Badarch, O., Lee., W. K., Kwak, D. A., Choi., S., Kokmila, K., Byun, J. G., and Yoo, S. J. 2011. "Mapping Forest Function Using GIS in Selenge Province, Mongolia." Forest Science and Technology 7 (1): 23-9.

[14] Maharjan, K. L., and Khatri-Chhetri, A. 2006. Role of Forest in Household Food Security: Evidence from Rural Areas in Nepal. Annual Report of Research Center for Regional Geography 15, Hiroshima University.

[15] FAO. 2013. "Forest and Water: International Momentum and Action." Food and Agriculture Organization of the United Nations, Rome. Accessed March 17, 2015. http://www.fao.org/docrep/017/i3129e/i3129e.pdf.

[16] Law of the Republic of Indonesia. 1999. "Law of the Republic of Indonesia No. 41 of 1999 Regarding Forestry." Accessed January 15, 2014. http://theredddesk.org/sites/default/files/uu41_99_en.pdf.

[17] Santoso, I. 2008. "Forest Area Zoning and Related Conflict." Jurnal Penelitian Sosial dan Ekonomi Kehutanan 5 (3): 143-53.

[18] Samndong, R. A., and Vatn, A. 2012. "Forest Related Conflicts in Southeast Cameroon: Causes and Policy Options." International Forestry Review 14 (2): 213-26.

[19] United Nations. 2008. "United Nations Declaration on the Rights of Indigenous Peoples." Accessed January 16, 2015. http://www.un.org/esa/socdev/unpfii/documents/ DRIPS_en.pdf.

[20] Sternberg, R. J., and Grigorenko, E. 2007. Teaching for Successful Intelligence: To Increase Student Learning and Achievement, 2nd ed.. California: Corwin Press. 